\title{
Evaluation of Different Fungicides for the Control of Net blotch (Pyrenophora teres) Disease on Barley (Hordeum vulgare L.) at West Showa Zone, Ethiopia
}

\author{
Nemomsa Beyene ${ }^{*}$ and Amsalu Abera
}

Department of Plant Sciences, College of Agriculture and Veterinary Sciences, Ambo University, P.O. Box 19 Ambo, Ethiopia

\begin{abstract}
Barley ranks fourth among the cereals in both yield and hectare coverage at global level next to wheat, rice and maize. Net blotch is one of the most important barley diseases which reduce both quality and quantity of barley grain. Currently, the disease can be controlled using different approaches. The aim of this work is to test the effectiveness of different fungicides. Progress 250 EC, Rexdou, Tilt 250 EC, Skyway Xpro EC 275 and Zantara EC 216 against net blotch of barley disease compared to unsprayed control. The experiment was conducted in west Showa Zone at the site which is well known as net blotch disease hot spot. The experiment was conducted on plots of $25 \mathrm{~m}^{2}$. The results showed that, significant $(\mathrm{P}<0.05)$ difference among treatments. Skyway Xpro EC 275 fungicide reduced the incidence, severity, grain yield loss, by 79.78, 88.98 and 49.97\%, over fungicide unsprayed treatments, respectively. Zantara EC 216 was second most effective fungicide to reduced disease incidence, severity, grain yield loss, and dry biomass loss by $57.33,75.58,36.21$, and $38.11 \%$, respectively. However, there was no significant difference among Progress 250 EC, Rex dou and Tilt250 EC fungicides. The Effectiveness of Skyway Xpro EC 275 and Zantara EC 216 for the control of barley net blotch disease revealed $18.88 \mathrm{q} /$ ha and $10.73 \mathrm{q} /$ ha, respectively, compared to fungicide unsprayed treatment. The grain yield and dry biomass obtained from plots treated by the fungicides were higher compare to fungicide unsprayed plot. It is evident that, the newly introduced fungicides (Skyway XproEC 275 and Zantara EC216) control the net blotch disease of barley effectively compared to the previously used fungicides under Ethiopian condition. Therefore, those fungicides recommended for barley net blotch disease management practices as foliar application.
\end{abstract}

Keywords: Barley; Ethiopian; Fungicide Efficacy; Net blotch

\section{INTRODUCTION}

Barley (Hordeum vulgare L.) is one of the most important crops grown worldwide at an altitude ranging from 1400 to 4000 meters above sea level [1]. At global level, barley ranks fourth among cereal crops in both yield and hectare coverage after wheat, rice and maize [2]. In Ethiopia, barley grown from 1500 to 3500 meters above sea levels predominantly as food crops [3] and ranks fifth after teff, maize, sorghum and wheat [4].

Barley is staple food for many people globally, especially for poor households, in addition to its uses in malting and as an animal feed [5]. Barley's grain used for the preparation of different foodstuffs in Ethiopia, such as malt production, injera, porridge, roasted grains; and different local drinks and the straw and stem stub are good source of feed for animals and roof thatching, respectively, in Ethiopia [6].

Barley productivity is low $(1.97 \mathrm{t} / \mathrm{ha})$ in Ethiopia as compared to world average of $3.1 \mathrm{t} / \mathrm{ha}$ and the reduction in productivity of the crop is mainly directed to multidimensional a biotic stresses and biotic stresses [7]. The American Phytopathological Society (2014) recorded thirty-six fungal, organisms causing barley diseases. In Ethiopia about 40 plant diseases, have been recorded on barley (EIAR, 2019). Among which net blotch, scald and leaf rust are the most three important barley diseases causing significant yield and quality loss [8]. Diseases such as scald, net

*Correspondence to: Nemomsa Beyene, Department of Plant Sciences, College of Agriculture and Veterinary Sciences, Ambo University, P.O. Box 19 Ambo, Ethiopia, Tel: +251 911943176; E-mail: nemomsa.beyene9@gmail.com

Received: November 28, 2019; Accepted: January 20, 2020; Published: January 27, 2020

Citation: Beyene N, Abera A (2020) Evaluation of Different Fungicides for the Control of Net blotch (Pyrenophora teres) Disease on Barley (Hordeum vulgare L.) at West Showa Zone, Ethiopia. J Plant Pathol Microbiol 11: 487. doi: 10.35248/ 2157-7471.20.11.487

Copyright: (C) 2020 Beyene N, et al. This is an open-access article distributed under the terms of the Creative Commons Attribution License, which permits unrestricted use, distribution, and reproduction in any medium, provided the original author and source are credited. 
blotch, spot blotch and rusts, can reduce yields by up to 67\% [9]. Net blotch had a limited distribution before the year 1984 in Ethiopia [10]. Currently, this disease is an ever endemic disease to the most parts of the highlands of the country [8] that causes an extensive grain yield loss in the country, $27 \%$ on an average and up to $34 \%$ when it is severe [11].

Controlling net blotch of barley using foliar fungicide has been reported by different authors [12] and [13]. The effectiveness of control using foliar fungicides varies depending on factors such as the degree of disease pressure, mode of action of the active ingredient, application rate, timing and number of applications, and reduced sensitivity or resistance in pathogen populations [14]. Despite of the huge losses caused by net blotch disease on barley, wide distribution of the disease in the country and susceptibility of several land race and improved varieties to the disease, research on net blotch management through different means is limited in Ethiopia [15]. Now days it is very economical to manage net blotch disease using foliar fungicide, particularly for susceptible varieties [16]. However, chemical options are not well exploited by most of Ethiopian farmers. Hence, to maximize more number of fungicide options in the market and to identify effective fungicides, frequent verification and evaluation of new fungicides against barley net blotch is important to sustain barley production and productivity. The aim of this study was to test the effectiveness different fungicides including the newly introduced (Skyway XproEC 275 and Zantara EC216) for the management of net blotch of barley caused by Pyrenophora teres.

\section{MATERIALS AND METHODS}

\section{The experimental site}

The experiment was conducted in west Showa Zone, Toke kutaye district, Oromia regional state, Ethiopia in 2018 G.C. The experimental site was selected perversely based on disease belt of net blotch of barley. The coordinate of the site was $8^{\circ} 54^{\prime} 59.99^{\prime \prime} \mathrm{N} 38^{\circ} 09^{\prime} 60.00^{\prime \prime} \mathrm{E}$ with altitude of 2129 meters above sea level. The minimum and maximum temperature of the Woreda ranges from $10.2-11.7$ and $21.8-24.4^{\circ} \mathrm{C}$, respectively, with a mean annual rain fall which ranges from 900-1100 mm. The main rainy season of the sites is from June to September and receives $70 \%$ of the annual rainfall.

\section{Experimental design, treatment and field management}

The experiment was arranged in randomized complete block design with three replications. The trial contained six treatments (Progress 250 EC, Rexdou, Tilt 250 EC, Skyway XproEC 275, Zantara EC216 and unsprayed control). The fungicides were applied at recommended rate (Table 1). During fungicide application, the plots under application sheltered with plastic sheet supported by four wooden poles to protect the drift of chemical to the next plots. The plots with nil fungicide treatments were sprayed with equal amount of water the experimental plot had the size of $5 \mathrm{~m} \times 5 \mathrm{~m}=25 \mathrm{~m} 2$. The spacing between each plot and replication was $1 \mathrm{~m}$ and $2 \mathrm{~m}$, respectively.

Table 1: Detail description of fungicides used in the study.

\begin{tabular}{|c|c|c|c|c|c|c|}
\hline $\mathrm{S} / \mathrm{N}$ & Trade name & Common name & Content of ingredients & $\begin{array}{l}\text { Formulatio } \\
\text { n type }\end{array}$ & $\begin{array}{l}\text { Manufacturer } \\
\text { company }\end{array}$ & $\begin{array}{l}\text { Application } \\
\text { rate }\end{array}$ \\
\hline 1 & & & & EC & & $0.5 \mathrm{l} / \mathrm{ha}$ \\
\hline 2 & $\begin{array}{l}\text { Skyway Xpro EC } \\
275\end{array}$ & $\begin{array}{l}\text { Bixafen+Prothioconazole } \\
+ \text { Tebuconazole }\end{array}$ & $\begin{array}{l}\text { Bixafen } 75 \mathrm{~g} / 1+\text { Prothioconazole } 100 \\
\mathrm{~g} / 1+\text { Tebuconazole } 100 \mathrm{~g} / 1\end{array}$ & EC & Bayer Crop Science & $1.25 \mathrm{l} / \mathrm{ha}$ \\
\hline 3 & Progress $250 \mathrm{EC}$ & Propiconazole & Propiconazole 25 g/1 & EC & $\begin{array}{l}\text { Asiatic Adricultural } \\
\text { industrial Pte. Ltd. }\end{array}$ & 0.5 l/ha \\
\hline 4 & Rex dou & $\begin{array}{l}\text { Epoxiconazole } \\
+ \text { Thiophanate-methyl }\end{array}$ & $\begin{array}{l}\text { Epoxiconazole } 187 \mathrm{~g} / 1+\text { Thiophanate- } \\
\text { methyl } 310 \mathrm{~g} / 1\end{array}$ & $\mathrm{SC}$ & $\begin{array}{l}\text { BASF East Africa } \\
\text { Limited }\end{array}$ & $0.75 \mathrm{l} / \mathrm{ha}$ \\
\hline 5 & Zantara EC 216 & Bixafen+Tebuconazole & Bixafen $50 \mathrm{~g} / 1+$ Tubicinazole $166 \mathrm{~g} / 1$ & EC & Bayer Crop Science & $1.25 \mathrm{l} / \mathrm{ha}$ \\
\hline 6 & control & - & - & - & - & - \\
\hline
\end{tabular}

Net blotch susceptible two-row barely variety (Sabini) which released from Kulumsa Agricultural Research Centre in 2011 year, was obtained from Holeta Agricultural Research Center and planted in row of $20 \mathrm{~cm}$ spacing on June 28, 2018 at rate of $100 \mathrm{~kg} / \mathrm{ha}$. The recommended rate $\left(41 / 46 \mathrm{~N} / \mathrm{P}_{2} \mathrm{O}_{5} \mathrm{~kg} / \mathrm{ha}\right)$ of both UREA and DAP fertilizer was used (split application (half at planting and half dose at 30 days of sowing) of urea fertilizer was made. All the dose of DAP fertilizer used as at planting. All the agricultural practices undertaken as recommended throughout the growing season of the crop uniformly for all plots of different treatments except application of fungicides. The fungicides were applied twice at seven day interval using knapsack sprayer to simulate practical application of farmer. The first fungicide application was madeas soon as the first symptom of net blotch observed on barley leaf (33 days after planting).

\section{Disease assessments}

Disease incidence and severity: Disease incidence and severity of net blotch were assessed three times from the middle rows, by excluding six rows (three rows from both sides) at every 7 days 
starting from six day of the first fungicide application. Scoring of the disease has started at about crop growth stage of 39 days after planting (DAP). The disease incidence and severity were assessed from the three top leaves: F, unfolded most top leaves, F-1, second most top leaves and F-2, the third most top leaves [17] of each tagged plants of 10 randomly selected tillers per plot.

Disease incidence was recorded by observing whether the net blotch symptom present or absent from ten randomly selected and tagged plant of the most top three leaves and converted to percentage of barley net blotch infected out of the total ten tagged plant.

Diseaseincidence $\%=\frac{\text { Numberof Diseasedplants }}{\text { Totalnumber of plantsinspected }} \times 100$

Net blotch severity data also recorded from the randomly selected and tagged most top fully emerged three leaves using disease severity scales of 0-6 [18]. The disease severity percentage calculated from severity scale as:

$D S(\%)=\frac{\sum(n v)}{N V} \times 100$

Where, $n$-is degree of infection on 6 grade scale;

$\mathrm{v}$-is the number of leaves per category;

$\mathrm{V}$ - is total number of leaves assessed;and

$\mathrm{N}$ - is the highest degree of infection

From the severity data, AUDPC for each treatment was calculated as described by Campbell and Madden [19] as follows:

$A U D P C=\sum_{i=1}^{n-1}[0.5(x i+x i+1)(t i+1-t i)]$

Where, xi- is the percentage of disease severity index at ith assessment;

ti -is the time of the ith assessment in days from the first assessment date; and

$\mathrm{n}$ - is the total number of days disease severity was assessed.

\section{Yield loss assessment}

Grain yield and biomass data were collected at the plot base and converted to hectare bases. The relative loss of yield (\%) due to the disease was calculated for the yield parameters.

Relative Yield loss $(\%)=\frac{{ }^{Y_{p}}-Y_{t}}{{ }{ }_{p}}$

Where, $\mathrm{Y}_{\mathrm{p}^{-}}$is the yield of maximum protected plot and

Table 2: Effect of fungicide application on barley net blotch, disease during 2018 cropping season.
$Y_{t}$ is yield from plots of other treatments.

\section{Fungicide efficacy}

Fungicide efficacy (EF) was calculated:

$E F(\%)=\frac{X-Y}{X} \times 100$

Where,

$\mathrm{X}$ - Disease severity in control,

Y - Disease severity in treated plots.

\section{Data analysis}

Analysis of Variance (ANOVA) was done by using SAS version 9.3, and means comparisons for the significantly different variables were made among treatments using Least Significant Differences (LSD) test at 0.05 levels of significance.

\section{RESULTS AND DISCUSION}

\section{Effect of fungicides on barley net blotch incidence and severity}

The result showed significant $(\mathrm{P}<0.05)$ difference among the treatments in reducing disease incidence at six day after fungicide application. Twice fungicide application at seven day interval significantly reduced net blotch disease incidence as compared to fungicide unsprayed at the third day of data recording (52 DAS) (Table 2). On the specified day of data recording, 98.89\% net blotch incidence was recorded from the fungicide unsprayed plots which was reduced to 20.00, 42.20, $66.67 \%, 71.13$ and $71.10 \%$, by Skyway Xpro EC 275, Zantara EC 216, Tilt 250 EC, Rex dou and Progress 250 EC fungicides, respectively, (Table 2). There was no significant difference disease incidence recording among Progress 250 EC, Rex dou and Tilt $250 \mathrm{EC}$ in reducing disease incidence. However, there was significant difference between the control and all other treatments and also between Skyway Xpro EC 275 and Zantara EC 216 fungicide at 14th day of the second fungicide application. Skyway Xpro EC 275 controlled net blotch disease incidence by 71.88 and $79.77 \%$ over Rex dou fungicide and the control (nil fungicide), respectively. Net blotch incidence of $94.70 \%$ on barley in central and northwest Ethiopia was reported [20]. Teshome et al. [21] reported that, the effect of propiconazole application is more pronounced in most susceptible varieties.

Mean Disease incidence

\begin{tabular}{llll}
\cline { 2 - 3 } Treatment & 38th Days after sowing & 45th Days after sowing & 52th Days after sowing \\
\hline Progress 250 EC & $23.33 \mathrm{~b}$ & $42.22 \mathrm{~b}$ & $71.10 \mathrm{~b}$ \\
\hline
\end{tabular}




\begin{tabular}{llll}
\hline Rex dou & $23.33 \mathrm{~b}$ & $38.89 \mathrm{~b}$ & $71.13 \mathrm{~b}$ \\
\hline Tilt 250 EC & $20.00 \mathrm{bc}$ & $44.45 \mathrm{~b}$ & $66.67 \mathrm{~b}$ \\
\hline Skyway Xpro EC 275 & $10.00 \mathrm{~d}$ & $17.78 \mathrm{c}$ & $20.00 \mathrm{~d}$ \\
\hline Zantara EC 216 & $12.22 \mathrm{~cd}$ & $28.89 \mathrm{bc}$ & $42.20 \mathrm{c}$ \\
\hline control & $33.33 \mathrm{a}$ & $64.45 \mathrm{a}$ & $98.90 \mathrm{a}$ \\
\hline LSD $(0.05)$ & 9.63 & 16.90 & 14.91 \\
\hline Cv & 25.98 & 23.55 & 13.28 \\
\hline
\end{tabular}

Means within the same columns followed by the same letters are not significantly different at $\mathrm{P}<0.05$ probability level.

The statistical analysis showed that there was significant $(\mathrm{P}<0.05)$ difference among treatments in reducing net blotch disease severity (Table 3). Even from visual field observation it is evident that, plots treated by the test fungicide fully deep green compared to the other treatments.

Table 3: The effect of fungicides application on disease severity of barley net blotch at three different time disease assessment.

\begin{tabular}{llll}
\hline \multirow{2}{*}{ Treatment } & \multicolumn{2}{c}{ Means of Net blotch disease severity at different disease recording time } \\
\cline { 2 - 4 } & 38th Days after sowing & 45th Days after sowing & 52th Days after sowing \\
\hline Progress 250 EC & $5.92 \mathrm{ab}$ & $16.29 \mathrm{bc}$ & $42.04 \mathrm{~b}$ \\
\hline Rex dou & $5.56 \mathrm{ab}$ & $25.18 \mathrm{~b}$ & $40.37 \mathrm{~b}$ \\
\hline Tilt 250 EC & $5.74 \mathrm{ab}$ & $21.67 \mathrm{~b}$ & $37.22 \mathrm{~b}$ \\
\hline SkywayXproEC275 & $2.04 \mathrm{~b}$ & $6.29 \mathrm{~d}$ & $8.52 \mathrm{~d}$ \\
\hline Zantara EC216 & $2.96 \mathrm{~b}$ & $10.56 \mathrm{~cd}$ & $18.89 \mathrm{c}$ \\
\hline Unsprayed plot & $9.45 \mathrm{a}$ & $36.48 \mathrm{a}$ & $77.37 \mathrm{a}$ \\
\hline Mean & 5.28 & 19.41 & 37.402 \\
\hline CV (\%) & 44.02 & 26.18 & 14.95 \\
\hline LSD (0.05) & 4.27 & 9.25 & 10.17
\end{tabular}

Treatment means within a columns followed by the same letter are not significantly different at $\mathrm{P}<0.05$.

Skyway Xpro EC 275 and Zantara EC216 fungicides significantly reduced disease severity compared to the other treatments whereas, Progress 250 EC, Rex dou and Tilt 250 EC fungicides treatments were not significantly reduced disease severity at 6th day of data recording (Table 3). At the last day of disease recording (52 days after sowing) or third day data recording, there was significant difference among treatment and the control in reducing net blotch of barley disease severity and there was no significant difference among Progress 250 EC, Rex dou and Tilt 250 EC treatments in reducing disease severity. At last day of data recording (52 days after sowing) the severity of net blotch disease on unsprayed plot (nil fungicide application) reached $77.37 \%$, which was reduced to $8.52,18.89$ and $37.22 \%$ on the plots sprayed by Skyway Xpro EC 275, Zantara EC 216 and Tilt 250 EC fungicide, respectively, (Table 3). Skyway XproEC 275 fungicide reduced net blotch disease severity by 88.98, 54.89 and $77.10 \%$ compared to the control, Zantara EC 216 and Tilt 250 EC fungicide treatment, respectively. This study was in line with finding of Bekele et al. [22] who revealed 5.75-83.82\% net blotch disease of barley severity reduction over unsprayed treatment using different fungicide. The experiment conducted by Wubishet et al. [13] on evaluation of integrated disease management for malt barley production in bale highlands, South-Eastern Ethiopia, also indicated that Tilt 250 EC fungicide application significantly reduced net blotch disease severity when applied twice 7-10 days intervals as compared to 
nil application. Milos et al. [23] reported that mixture of fungicide pyraclostrobin + epoxiconazole resulted in the lowest disease severity.

\section{Effect of fungicides on area under disease progress curve (AUDPC) of barley net blotch disease}

There was significant $(\mathrm{P}<0.05)$ difference between fungicide treatments and the control in reducing the AUDPC of net blotch disease of barley when applied at seven days intervals. The area under disease progress curve of the nil application plots (control) was 592.30 which was reduced to 88.48, 160.78, 301.33 , 322.13, and $324.30 \%$ by Skyway Xpro EC 275, Zantara EC216, Progress 250 EC, Tilt 250 EC and Rex dou fungicides
(Figure 1). However, there was no significant difference among Progress 250 EC, Tilt 250 EC and Rex dou in reducing the AUDPC. Skyway Xpro EC 275 fungicide reduced the AUDPC by $85.06,70.64$ and $44.97 \%$ over the control, Progress 250 EC and Zantara EC 216 fungicides, respectively. This study was in line with the experiment done by Bekele et al. [22] on barley net blotch epidemiology and management which indicated that fungicide application reduced AUDPC from 11.38-84.81\% over non-fungicide applied treatment. Skyway Xpro EC 275 fungicide showed $72.52 \%$ reduction of AUDPC over the Tilt 250 EC fungicide. Significant reduction of AUDPC of net blotch disease of barely obtained by applying Tilt 250 EC fungicides at 7, 14 and 28 day interval [21].

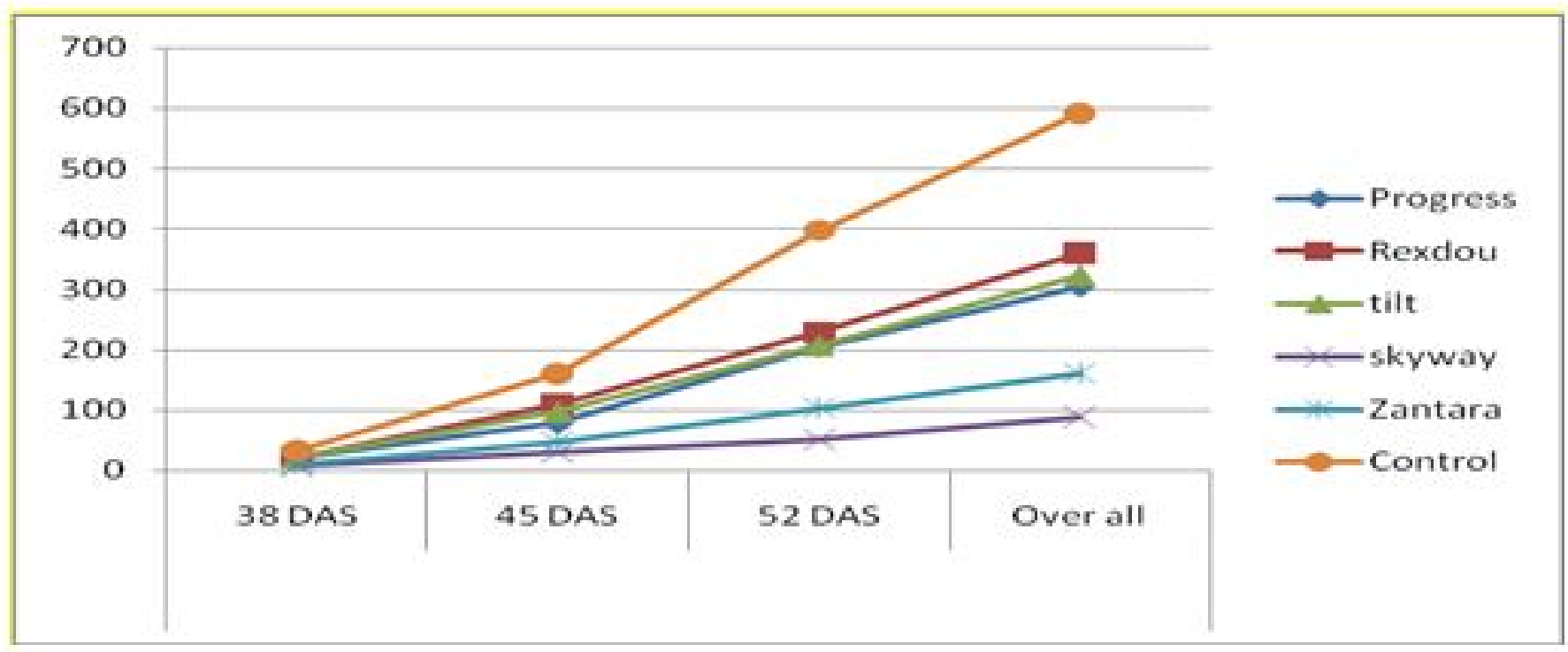

Figure 1: Graph showing the AUDPC of barley net blotch treated with different fungicide and control for three consecutive disease recording time.

Effect of fungicides on reducing yield loss on barley crop affected by net blotch disease

The statistical analysis showed that there was significant $(\mathrm{P}<0.05)$ difference among fungicides sprayed and unsprayed plot on biomass yield (Table 4). The dry biomass from the plots treated by the Skyway Xpro EC 275 fungicide and Zantara EC216 fungicide were 111.12 and $99.230 \mathrm{q} /$ ha which were not significantly different from each other statistically. The dry biomass obtained from Tilt 250 EC, Rex dou, Progress 250 EC and control was reduced to 87.04, 81.85, 73.52 and $61.41 \%$, respectively. There was no significant difference among Tilt 250 EC, Progress 250 EC and Rex dou fungicide on dry biomass of barley crop infected by net blotch disease. Skyway Xpro EC 275 fungicide reduced biomass yield loss due to net blotch of barley by $44.73 \%$ over the control.

Table 4: Evaluation of fungicides efficacy against net blotch diseases incidence, severity, biomass, yield and AUDPC of barley 2018 main cropping season.

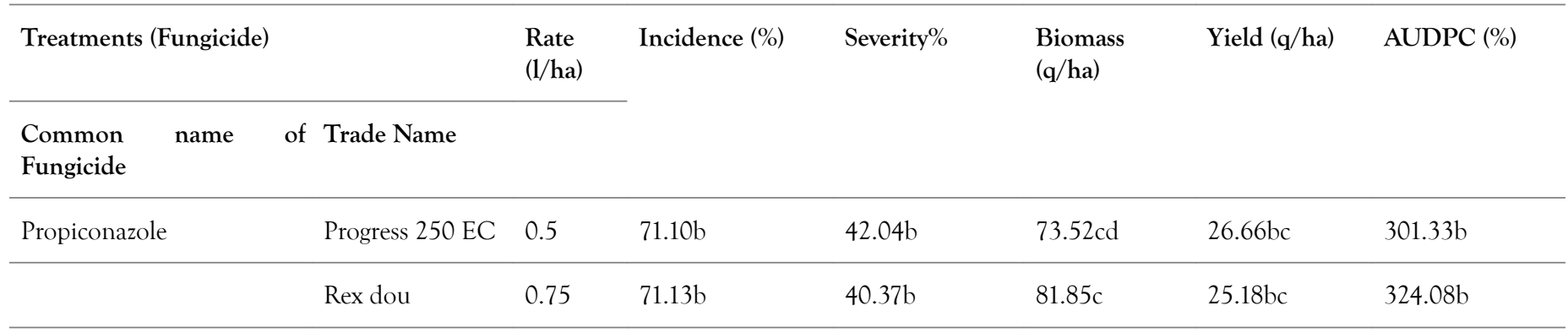




\begin{tabular}{llllllll}
\hline $\begin{array}{l}\text { Bixafen+Prothioconazole } \\
+ \text { Tebuconazole }\end{array}$ & $\begin{array}{l}\text { Skyway Xpro EC } \\
275\end{array}$ & 1.25 & $20.00 \mathrm{~d}$ & $8.52 \mathrm{~d}$ & $111.11 \mathrm{a}$ & $37.78 \mathrm{a}$ & $88.48 \mathrm{c}$ \\
\hline Bixafen+Tebuconazole & Zantara EC 216 & 1.25 & $42.20 \mathrm{c}$ & $18.89 \mathrm{c}$ & $99.23 \mathrm{ab}$ & $29.63 \mathrm{~b}$ & $160.78 \mathrm{c}$ \\
\hline Propiconazole & Tilt 250 EC & 0.5 & $66.67 \mathrm{~b}$ & $37.22 \mathrm{~b}$ & $87.04 \mathrm{bc}$ & $22.96 \mathrm{~cd}$ & $322.13 \mathrm{~b}$ \\
\hline- & Nil (control) & - & $98.90 \mathrm{a}$ & $77.37 \mathrm{a}$ & $61.41 \mathrm{~d}$ & $18.89 \mathrm{~d}$ & $592.30 \mathrm{a}$ \\
\hline Mean & & 63.02 & 37.402 & 85.71 & 26.85 & 298.18 \\
\hline CV (\%) & & 13.16 & 14.95 & 10.73 & 12.46 & 22.26 \\
\hline LSD (0.05) & & 14.91 & 10.17 & 16.72 & 6.08 & 120.76 \\
\hline
\end{tabular}

Treatment means within a columns followed by the same letter are not significantly different at $\mathrm{P}<0.05$.

Significant $(\mathrm{P}<5 \%)$ differences also observed between fungicides sprayed and unsprayedplot in grain weight but there was no significant differences between the plot treated by Tilt 250 EC fungicide and no fungicide sprayed in grain yield (Table 4). Skyway Xpro EC 275 fungicide revealed better grain yield which was $37.14 \mathrm{q} /$ ha $(3.71 \mathrm{t} / \mathrm{ha})$, followed by Zantara EC 216 (29.63 q/ha), Progress 250 EC (26.66 q/ha) and Rex dou (25.18 q/ha) (Table 4). Skyway Xpro EC 275 fungicide showed 49.14\% yield advantage over the nil fungicide applied plot. Wanyera et al. [24] also reported $50 \%$ higher yield of wheat crop from fungicide treated as compared to untreated plot in Kenya. Skyway Xpro EC 275 fungicide provided $8.18 \mathrm{q} /$ ha yield advantage over the plot treated by the second best (Zantara EC 216) fungicide affecting yield of barley infected by net blotch disease. Using Zantara EC 216 fungicide to control net blotch disease of barley had $36.25 \%$ over the nil application. About 35.3\% increment in yield of barley grain was also reported by Miloš et al. [23] by application of combination pyraclostrobin+epoxiconazole fungicide on crops attacked by net blotch of barley. The authors also reported that two times applications of mixture of fungicides on barley crop attacked by net blotch disease increased grain yield by $22.6-43 \%$ compared to the untreated plots. There was no significant difference among Progress 250 EC, Rex dou and Tilt 250 EC fungicide in affecting the yield when applied on barley crops infected by net blotch disease. However, there was significant different between the control and Progress 250 EC or Rex dou sprayed plot on grain yield. Even though there was no significant difference between the Tilt 250 EC and nil fungicide application, using Tilt 250 EC fungicide provided $4.07 \mathrm{q} /$ ha advantage over the nil fungicide application.

The yield obtained using the Skyway Xpro EC 275 fungicide was in agreement to the study conducted by Bekele et al. [22] on barley net blotch epidemiology and management which revealed that, treating barley crop by propiconazole at seven day interval for 11 and 14 times for two consecutive (2011 and 2012) years, increased the yield of barley to (2.45 -3.79 t/ha). Grain yield and dry biomass of barley was negatively correlated to severity of net blotch at every disease recording (data was not presented).

\section{Effect of fungicides on barley crop}

There was no any phytotoxic effect observed on barley crop due to the fungicide application to control net blotch disease development. Even the plot treated with Skyway Xpro EC 275 and Zantara EC 216 were more green and beautiful compared to other plots.

\section{Fungicide efficacy (FE)}

The result of the analysis indicated that, Skyway Xpro EC 275 showed highest level of efficacy $(88.89 \%)$, followed by Zantara EC 216 (75.58\%) compared to the control. Tilt 250 EC, Rex dou and Progress 250 EC showed 51.89, 47.82, 45.66\% efficacy compared to the control treatment. Skyway Xpro EC 275 fungicide was also effective to reduced grain yield loss of barley due to net blotch disease by $49.97 \%$ as compared to control treatment. The second best effective fungicide reduced yield loss by $36.25 \%$ as compared to control treatment.

\section{CONCLUSION}

The experiment result showed that, almost all the fungicides were showed significant difference compared to the control treatments in all variables. Two fungicides (Skyway Xpro EC 275 and Zantara EC216) showed most effective in controlling barley net blotch disease. There was no significant difference among Progress 250 EC, Rex dou and Tilt 250 EC fungicide in reducing barley net blotch disease and reducing yield loss of barley. Therefore, based on this experiment, Skyway Xpro EC 275 (Bixafen+Prothioconazole+Tebuconazole) can be recommend for the management of barley net blotch disease under field conditions of West Showa Zone, Oromia Regional State, Ethiopia.

\section{REFERENCES}

1. Zemede A. The barley of Ethiopia: On-farm conservation of crop diversity. Lewis, Publishers, Boca Raton, Florida, USA. 2002.

2. Munck L. Barley for food, feed and industry: Theory and Practice. American Association of Cereal Chemists, St. Paul, MN, USA. 1981. 
3. Berhane L, Hailu B, Fekadu A. Barley production and research. In: Hailu-Gebre and J.A.G. Van Leur (Eds.). Barley Research in Ethiopia: Past Work and Future Prospects. Proceedings of the 1st Barley Research Review Workshop, 16-19 October 1993, Addis Ababa. IAR/ICARDA, Addis Ababa, Ethiopia. 1996. p. 1-8.

4. Abdi A. Barley genetic resources collection and conservation in Ethiopia: Barley Research and Development in Ethiopia. 2011.

5. Newton A C, Johnson SN, Gregory PJ. Implications of climate change on diseases, crop yields and food security. Euphytica. 2011;179:3-18.

6. Fenta A. Effect of fertilizer on growth response of food barley ( Hordeum Vulgare L.). Agricultural journal. 2018;13:40-47.

7. EIAR, Ethiopian Institute of Agricultural Research. Field crops research. 2019.

8. Yitbarek S, Bekele H, Getaneh W, Dereje T. Disease surveys and loss assessment studies on barley: In Hailu Gebre and Joop van Leur(Eds.). 1996;105-115.

9. Chilot Y, Fekadu A, Woldeyesus S. Barley-based farming systems in the highlands of Ethiopia. Ethiopian Agricultural Research Organization (EARO), Addis Ababa, Ethiopia. 1998.

10. Eshetu B. Review of research on diseases of barley, tef and wheat in Ethiopia, pp: 79-108. In A Tsedeke (Eds). A review of crop protection research in Ethiopia, Proceedings of the first crop protection symposium 4-7 February, 1985, Addis Ababa, Ethiopia. 1985.

11. Yitbarek S Wudneh E. Preliminary studies on the yield losses due to net blotch in barley, pp. 47-52. In Proceedings of the 10thEPC annual meetings. Addis Ababa, Ethiopia. 1985.

12. McLean MS. The epidemiology and control of spot form of net blotch of barley in Victoria, Australia. Ph.D thesis. School of Botany, University of Melbourne, Australia. 2011.

13. Wubishet A, Bekele H, Tilahun B. Evaluation of integrated disease management for malt barley production in bale high lands, South Eastern Ethiopia. Global Journal of Pest and Disease. 2015;3:108-112.
14. Vanaden Berg CGJ, Rossnagel BG. Effect of Tilt 250 EC on severity of spot type net blotch, grain yield and yield components in barley. Canadian Journal of Plant Science 1990;70:473-480.

15. Bedasa M. Selection of barley varieties for their yield potential at low rainfall area based on both quantitative and qualitative characteristics in North West Tigray, Shire, Ethiopia. International Journal of Plant Breeding and Genetics. 2014;8:205-213.

16. Sooväli P, Koppel M, Lauringson E, Talgre L. The advantage of decision support system for managing spring barley disease in Estonia. Agronomy Research. 2017;15:2134-2143.

17. Jayasena KW, Loughman R, Majewski J. Evaluation of fungicide in control of spot type net blotch on barley. Crop Protection. 2002;21:63-69.

18. Townsend GR, Heuberger JW. Methods for estimating losses caused by diseases in fungicide experiments. Plant Disease Report. 1943:27:340-343.

19. Campbell C L, Madden LV. Introduction to Plant Disease Epidemiology. John Wileey and Sons New York, USA. 1990.

20. Asnakech T. Relative importance and pathogenic variability of barley net and spot form of net blotch (Pyrenophora teres) in North West and Central Highlands of Ethiopia. Thesis, Haramay University. 2002;1-90.

21. Teshome G, Chemeda F, Geremew B. Effects of Net Blotch (Pyrenophora teres) on Malt Barley Yield and Grain Quality at Holeta Central Ethiopia. East Africa Journal of Science. 2008;2:150-158.

22. Bekele H, Sangchote S, Sarobol E. Barley Net Blotch Epidemiology and Management. Kasetsart Journal of Natural Science. 2004;38:380-392.

23. Miloš S, Emil R, Svetlana M, Ivana P, Biljana T. Field efficacy of different fungicide mixtures in control of net blotch on barley. Pestic. Phytomed. 2016;31:51-57.

24. Wanyera R, Macharia J K, Kilonzo SM, Kamundia JW. Foliar fungicides to control wheat stem rust, race TTKS (Ug99), in Kenya. Plant Disease. 2009;93:929-932. 